\title{
Patient participation in hand hygiene among health professionals
}

\author{
Participação do paciente na higienização das mãos entre profissionais de saúde \\ Participación del paciente en la higienización de las manos entre profesionales de salud
}

\begin{abstract}
Adriana Cristina de Oliveira', Selma de Almeida Pinto'
'Universidade Federal de Minas Gerais, Postgraduate Program in Nursing. Belo Horizonte, Minas Gerais, Brazil.

How to cite this article:

Oliveira AC, Pinto AS. Patient participation in hand hygiene among health professionals. Rev Bras Enferm [Internet]. 2018;71(2):259-64. DOI: http://dx.doi.org/10.1590/0034-7167-2016-0124

\section{Submission: 03-07-2017 Approval: 04-07-2017}

\section{ABSTRACT}

Objective: To investigate the perception and attitude of health professionals (HPs) about the patient participation in hand hygiene $(\mathrm{HH})$. Method: A cross-sectional study with $150 \mathrm{HPs}$ from a university hospital in Brazil. A descriptive analysis was conducted. Results: Simple hand hygiene was the preferred method of HPs, rather than hand rubbing with alcohol-based solutions. A total of $83.3 \%$ of the HPs supported the patient participation in reminding them about $\mathrm{HH}$, but $48 \%$ reported that they would feel uncomfortable; $45.3 \%$, comfortable; and $20.7 \%$ were familiar with the "Patients for Patient Safety" program. Conclusion: HPs showed limited knowledge about $\mathrm{HH}$, opposing recommendations on the topic. The contradiction between the HPs acceptance and attitude when questioned by the patient regarding $\mathrm{HH}$ was revealed, reflecting a lack of knowledge about the WHO program and the need to implement educational practices in health.
\end{abstract}

Descriptors: Health Professionals; Hand Hygiene; Patient Participation; Patient Safety; Hospital Infection.

\section{RESUMO}

Objetivo: Investigar a percepção e atitude dos profissionais de saúde (PS) sobre a participação do paciente na higienização das mãos (HM). Método: Estudo transversal, realizado com 150 PS de um hospital universitário do Brasil. Realizou-se uma análise descritiva. Resultados: A higiene simples das mãos foi o método preferido dos PS, em detrimento da fricção com preparação alcoólica. Dos PS, 83,3\% apoiavam à participação do paciente em lembrá-los sobre a HM, mas $48 \%$ relataram que se sentiriam desconfortáveis; 45,3\%, confortáveis; e 20,7\% conheciam o programa "Paciente Pela Segurança do Paciente". Conclusão: PS mostraram conhecimento limitado sobre a $\mathrm{HM}$, contrapondo as recomendações sobre o tema. Revelou-se a contradição entre a aceitação e atitude dos PS em serem questionados pelo paciente a respeito da HM, refletindo desconhecimento do programa da OMS e a necessidade de implementação de práticas educativas em saúde.

Descritores: Pessoal da Saúde; Higiene das Mãos; Participação do Paciente; Segurança do Paciente; Infecção Hospitalar.

\section{RESUMEN}

Objetivo: Investigar la percepción y actitud de profesionales de salud (PS) sobre la participación del paciente en la higienización de manos (HM). Método: Estudio transversal, realizado con 150 PS de un hospital universitario de Brasil. Se realizó un análisis descriptivo. Resultados: La higiene simple de manos fue el método preferido de los PS, en detrimento de la fricción con preparación alcohólica. De los PS, 83,3\% apoyaban a la participación del paciente en recordarlos sobre la HM, pero $48 \%$ relataron que se sentirían incómodos; 45,3\%, confortables; y 20,7\% conocían el programa "Pacientes en Defensa de su Seguridad". Conclusión: Los PS mostraron conocimiento limitado sobre HM, contraponiendo las recomendaciones sobre el tema. Además, revelaron contradicción entre su aceptación y actitud a respecto de que sean cuestionados por el paciente sobre la HM, refletando desconocimiento del programa de la OMS y la necesidad de implementación de prácticas educativas en salud.

Descriptores: Personal de la Salud; Higiene de las Manos; Participación del Paciente; Seguridad del Paciente; Infección Hospitalera. 


\section{INTRODUCTION}

Hand hygiene $(\mathrm{HH})$ has been considered, for more than 150 years, the most important measure to reduce the crosstransmission of microorganisms in health services. This practice is recognized above all as a simple, effective and cost-effective way to reduce healthcare-associated infections (HAIs) by international agencies such as the World Health Organization (WHO) and Centers for Disease Control and Prevention (CDC) and Brazilian national agencies such as Agência Nacional de Vigilância Sanitária - National Agency of Sanitary Surveillance (ANVISA) ${ }^{(1-3)}$.

However, despite all the evidence about the relevance of $\mathrm{HH}$ to the breakdown of the microorganism transmission chain and its effectiveness in the prevention of HAls, compliance with this practice by health professionals is reported as unsatisfactory throughout the world, with an estimate of lower rates to $50 \%{ }^{(4-7)}$.

The factors pointed to explain the low adherence to $\mathrm{HH}$ among HPs are associated with forgetfulness, beliefs and inadequate knowledge; dryness and skin lesions; excess of activity or insufficient time; physical structure-related problems such as sinks which are far or inaccessible to the professional; lack or low quality of inputs such as soap, paper towel and alcoholbased solutions, among others ${ }^{(6-8)}$.

Thus, several initiatives have been developed by international and national bodies, societies and associations of infection control professionals, in order to increase $\mathrm{HH}$ adherence among HPs, such as WHO's First Global Patient Safety Challenge of Clean Care is Safer Care, which aims to reduce the occurrence of HAIs through actions related to the improvement of $\mathrm{HH}^{(1-5)}$.

In this perspective, the "Patients for Patient Safety" program, which proposes to ensure the patient participation in all healthcare levels, is highlighted, with an emphasis on improving $\mathrm{HH}$ adherence, reminding health professionals to perform it before their care ${ }^{(2,9)}$.

Regarding $\mathrm{HH}$, informing and educating patients to participate in their own care is a relatively recent strategy proposed by WHO. Positive results have been demonstrated in international studies on increasing $\mathrm{HH}$ adherence in health services ${ }^{(2,10-11)}$.

However, this program is still little publicized, and the reports about it are more focused on the North American experience. In Brazil, despite the growing interest in its implementation and in WHO recommendations for its implementation, there are no studies that report how patient involvement has developed as a strategy to improve $\mathrm{HH}$ among health professionals. Therefore, the objective of this study was to investigate the perception and attitude of health professionals regarding patient participation in hand hygiene in the perspective of the patients for patient safety program.

\section{METHOD}

\section{Ethical aspects}

This study is part of the project Impacto da estratégia multimodal na adesão à higiene de mãos entre a equipe multiprofissional (Impact of the multimodal strategy on the adherence to hand hygiene among the multiprofessional team) submitted and approved by the Research Ethics Committee of the Federal University of Minas Gerais (COEP/UFMG).

\section{Study design, location and period}

This present research consisted of a cross-sectional approach, conducted in a public university hospital in Belo Horizonte, Minas Gerais, Brazil, from August to October 2015.

\section{Population and inclusion and exclusion criteria}

One hundred and fifty health professionals were interviewed individually at the their workplace. The participants were selected according to the inclusion criteria: being a medical professional or being in the nursing team; working in medical-surgical clinic units; and provide direct patient care. Exclusion criteria were as following: health absent professionals in the sector, due to leave, vacations or medical leave during the period of data collection.

\section{Instrument of data collection}

The study used a structured questionnaire, based on the model developed by $\mathrm{WHO}(2)$. This was adapted to local reality and previously tested in the pilot study. The instrument of data collection was divided into five parts: I - sociodemographic characteristics; II - perception of health professionals in relation to HAls and $\mathrm{HH}$; III - perception of health professionals regarding compliance with hand hygiene; knowledge of health professionals regarding the structure of the unit and materials for $\mathrm{HH}$; IV - perception and attitudes of health professionals regarding the patient participation in hand hygiene.

\section{Statistical and result analyses}

The collected data were analyzed in the Statistical Package for Social Sciences program (SPSS), version 21, through descriptive statistics to summarize the obtained data set.

\section{RESULTS}

Regarding the sociodemographic characteristics of the 150 health professionals interviewed, $55.3 \%$ were nursing technicians; $26 \%$ were nurses; and $18.7 \%$, doctors; with a predominance of females $(74.7 \%)$. The mean age was 35 (22-64 years). The mean time of professional training was 9 years and the professional performance of the interviewees in the institution was 4.6 years.

Regarding the perception of health professionals about HAls, all participants reported being aware and concerned about the risk of patients acquiring them, and $90.7 \%$ considered that HAls represent a highly relevant issue. Most health professionals $(90 \%)$ considered the $\mathrm{HH}$ to be highly effective in reducing care-related infections, and $94.7 \%$ believed that this practice was very important when performed before and after contact with patients to prevent infection. Regarding the professionals' preference of $\mathrm{HH}$ type, hand washing with soap and water $(78 \%)$ was preferred, rather than the hand rubbing with alcohol-based solutions (22\%).

The reasons reported by professionals for hand hygiene with soap and water were, for $43.6 \%$, related to efficacy; 
$24.8 \%$, to practicality; $19.7 \%$, due to habit/custom; and $12 \%$ did not express the reason for their preference. Regarding the use of alcohol-based solutions, $69.7 \%$ attributed their choice to practicality; $12.1 \%$ due to effectiveness; $3 \%$, habit/custom; and $15.2 \%$ did not inform the reason for the choice. Training on $\mathrm{HH}$ was reported by $52.7 \%$ of the HPs, admitted in the institution, in the last year.

In face of the perception of the health professionals regarding hand hygiene compliance, they stated performing $\mathrm{HH}$ with soap and water in $57.6 \%$ of the moments before and after the contact with patients; and hand rubbing with alcoholbased solutions, in $39.3 \%$, which is restricted to the moment before having contact with patient.

Regarding the structural aspects of the units and the products that contribute to $\mathrm{HH}$ compliance, a large part of health professionals considered the availability of water, soap and paper towel, trash bins without manual contact, sinks in the units and alcohol-based solutions to be very important. Most of the interviewees considered that the institution had all the products and materials for $\mathrm{HH}$.

As to the incentive to the practice of $\mathrm{HH}, 57.3 \%$ of the professionals recognized the incentive of their direct superior as important; $81.3 \%$, the institution's incentive; and 32\%, the attitudes of colleagues.

Regarding national regulations and guidelines for $\mathrm{HH}$, $37.3 \%$ reported knowledge of the Resolução Diretoria Colegiada (Resolution Collegiate Board of Directors) (RDC) 42, 2010, of the National Sanitary Surveillance Agency, which stipulates the obligation to provide alcohol-based solution for antiseptic hand rubbing with the goal of establishing and promoting $\mathrm{HH}$ in the country's health services, in accordance with WHO guidelines in the World Alliance for Patient Safety. And $56.7 \%$ stated that they knew the "Five Moments for Hand Hygiene," an information that guides the specific situations in which $\mathrm{HH}$ is necessary, closely linked to the activities of health professionals and their involvement with the care/services close to the patient. On this topic, $8.1 \%$ correctly described these moments for $\mathrm{HH}$.

According to the perception and attitudes of health professionals regarding patient participation in hand hygiene, the majority of the interviewees $(83.3 \%)$ considered that the patients could help improving $\mathrm{HH}$, by reminding health professionals about this practice $(52.2 \%)$, aiming to promote greater patient protection/safety $(25.6 \%)$, since it is a patient's right $(11.2 \%)$ and in order to avoid/prevent infection $(8 \%)$. On the other hand, $16.7 \%$ of the interviewees did not view this participation as positive, claiming it to be unnecessary (60\%), not the patient's function (24.0\%), and embarrassing, the patient reminding the professional about $\mathrm{HH}(16.0 \%)$.

The majority of professionals $(93.3 \%)$ considered the patient participation to be important, in reminding the professionals about $\mathrm{HH}$; whereas, $19.3 \%$ of the interviewees were previously questioned by patients or relatives.

When questioned about their feelings about being reminded by patients about $\mathrm{HH}, 48 \%$ of the total of 150 participants reported that they would feel uncomfortable; $45.3 \%$, comfortable; and $6.7 \%$, very comfortable.
When questioned about strategies that would make it easier for patients to identify HPs willing to be questioned about $\mathrm{HH}, 53 \%$ of the professionals considered it important to display posters in patient units, written statements/booklets as well as verbal guidance, and $41.3 \%$ considered the use of badges with phrases that would encourage the patients to such questioning as unimportant.

Regarding the WHO "Patients for Patient Safety" program, $20.7 \%$ of the participants reported knowing about it, and $45.2 \%$ of them indicated that its foundation would be patient involvement in care.

\section{DISCUSSION}

Regarding the perception of interviewed health professionals about HAIs, the majority of them were aware of the risk of patients acquiring infections through the care service. Also, they considered that this was a high risk. A similar result was found by Kim et al. (2015).

The health professionals of this study reported preference for simple $\mathrm{HH}$, instead of hand rubbing with alcohol-based solutions, because they considered $\mathrm{HH}$ to be more effective. Possibly, the health professionals in this study do not recognize the indications and effectiveness of the types of $\mathrm{HH}$, which may have influenced the greater adoption of simple $\mathrm{HH}$ in relation to hand rubbing with alcohol-based solutions, in addition to the situations in which they must be performed.

This inference can be influenced by the data that only $52.7 \%$ of health professionals reported having received training on $\mathrm{HH}$ in the institution, directly reflecting the low recognition of alcohol's effectiveness for hand rubbing, consequently, the preference for simple hand hygiene was justified by practicality, which is not consistent with $\mathrm{WHO}$ recommendations ${ }^{(1-3)}$.

The encouragement of the use of alcohol-based products has been considered a strategy to increase health professionals' adherence to $\mathrm{HH}$ and to reduce the rate of HAls, by reducing the time spent with this practice and due to the rapid and effective reduction of microbial load. In the findings of this study, the lack of the HPs' proficiency in $\mathrm{HH}$, as well as a lack of knowledge of the effectiveness of $\mathrm{HH}$ products and types is clearly evident $^{(1-3,9,12)}$.

HPs preference for simple hand hygiene is still a major challenge in several countries, as pointed out by Bathke et al. (2013), in establishing that, among the opportunities for $\mathrm{HH}$, performed by monitored health professionals, in $90.5 \%$ of the situations, used soap and water; $6 \%$ alcohol-based solution; $2.4 \%$, water, liquid soap followed by alcohol-based solution; and $1.2 \%$, water and degermant solution ${ }^{(6)}$.

In this study, it was identified that, although $\mathrm{HH}$ is one of the most studied themes under different aspects, its comprehension and adoption in clinical practice still serve as the cornerstone for providing safe healthcare, which is evidenced worldwide by the low rates of their compliance among health professionals ${ }^{(1-3-6)}$.

In this study, most interviewees reported that all products and materials that contribute to $\mathrm{HH}$ were available at the institution. This finding differs from other studies that have shown lack of inputs such as water, soap, alcohol-based solutions and paper towel, and the absence of these products was 
mentioned as one of the factors for the low adhesion to $\mathrm{HH}$ by $\operatorname{HPs}^{(2,6,13-14)}$.

The change of the system, according to the $\mathrm{WHO}$ proposal, established in the "A Guide to the Implementation of the WHO Multimodal Hand Hygiene Improvement Strategy" in health services aims to ensure the availability of the materials necessary for the practice of hand hygiene by health professionals, including continuous and safe access to water and materials such as liquid soap, paper towels and, in particular, the availability of alcohol-based solutions, whether in liquid form, gel or foam ${ }^{(2)}$.

Most of the health professionals followed in this study, which was directly involved in patient care, were unaware of the Resolution of the Collegiate Board 42, legislation in force in Brazil since 2010, which may justify the reduced use of alcohol-based solutions in the health service, as well as the knowledge of its indications and effectiveness ${ }^{(15)}$.

In addition, the observed inadequacies regarding the preference for the use of soap and water as well as the predominance of the adoption of $\mathrm{HH}$ restricted to before and after the contact with the patient can be explained by the lack of knowledge of the "Five Moments for Hand Hygiene."

This finding is alarming, as it brings to light the limitation of perception of the HPs to the necessity of $\mathrm{HH}$ in the moments related to the handling of invasive devices during patient care, when moving from a contaminated body site to another, after contact with bodily fluids or excretions, mucous membrane, non-intact skin or wound dressings; after removal of gloves and, especially, after contact with inanimate objects and surfaces immediately next to the patient, understanding that environment and equipment can be considered as potential reservoirs of microorganisms ${ }^{(1-3,16)}$.

In clinical practice, the application of the "Five Moments for Hand Hygiene" actually remains as a challenge, in which the HPs recognize $\mathrm{HH}$ as a fundamental measure for prevention/reduction of HAls, of the dissemination of bacterial resistance. However, HPs are not yet able to recognize the situations that require $\mathrm{HH}$ adoption and, consequently, do not adopt it effectively ${ }^{(17-18)}$.

Although Pan et al. (2013) have shown that $83.1 \%$ of the 880 health professionals evaluated showed good knowledge of the five moments for $\mathrm{HH}$, this is not compatible with the reality of other countries and healthcare institutions ${ }^{(17-19)}$.

In the study by Souza et al. (2015), performed in a Brazilian Intensive Care Unit, the data that in $81.6 \%$ of cases $\mathrm{HH}$ was not performed "before aseptic procedure"(17), is also alarming. However, according to self-reported rates of intensive care nurses in Turkey, 65\%-93\% performed $\mathrm{HH}$ before and 96$100 \%$ after procedures with patients ${ }^{(20)}$.

The support for patient participation in reminding professionals about $\mathrm{HH}$ is in line with the findings of Pan et al. (2013) and Longtin et al. (2009), in which $62.8 \%$ and $73 \%$ of the health professionals surveyed agreed with patient participation in $\mathrm{HH}$, respectively ${ }^{(19-20)}$.

Among the reasons considered by the interviewees to support the patient participation in $\mathrm{HH}$, most answered that this attitude would increase the compliance of $\mathrm{HH}$ among health professionals due to forgetfulness. However, among those who disapproved of the patient's involvement in $\mathrm{HH}$, claims mainly revolved around the premise that this strategy was unnecessary, since such attitude is not the patients' function and that the HPs know their obligation. This data contrasts with Kim et al. (2015), as the reason given by the health professionals when disagreeing with the patient participation referred to their concern with the negative effects this intervention may have on their relationship with the patients ${ }^{(11)}$.

On the other hand, studies that investigated how patients feel about questioning HPs about $\mathrm{HH}$ stated that they did not feel comfortable asking the HPs, as there are the possibilities of retaliation, interference and detriment to the treatment given by the professionals ${ }^{(11,21-22)}$.

Although most healthcare professionals in the study supported patient participation and considered it important to remind patients about this practice, an expressive number of HPs that were still supportive reported that they would feel uncomfortable being questioned by patients if they performed any type of $\mathrm{HH}$. This finding was corroborated by the results of the study by Kim et al. (2015) ${ }^{(11)}$.

Strategies for using badges stating "Ask me if I sanitized my hands" were considered to be of little relevance to respondents, stating that they would not like to use them, consistent with the statements of Longtin et al. (2009), in which $37 \%$ would not consent to use badges to invite patients to ask about hand hygiene ${ }^{(20)}$.

The use of "Ask Me if I Sanitized My Hands" badges is considered an important tool to educate and encourage patients to remind professionals about $\mathrm{HH}$. However, in this study, it was observed that, in fact, the interviewees (physicians, nurses and nursing technicians) were not open to questioning, since the majority did not want to use them. As HPs reported approving patient participation in reminding them on how to sanitize their hands, not wanting to wear the badges is clearly a contradiction between accepting patient participation in this process, but not committing to adopting attitudes that lead them to such behavior.

\section{Limitation of study and contribution to health}

As limitations of the research, the fact that it was conducted in a single institution with a method of convenience sampling, as well as the shortage of specific scientific literature involving the patient participation in adherence to $\mathrm{HH}$ at the time of the research. Although these limitations have been present, the contribution to the practice of nursing and health professionals from the results obtained points to relevant reflections, in which it is evident that the professionals of health, although they often verbally assume the relevance of patient participation in their treatment and in encouraging good practices, do not always incorporate postures and positive attitudes that in fact influence and encourage patients to such involvement and co-responsibility for their treatment. The results of our study also indicate that training and continuing education in this aspect of patient involvement in improving care practices should be planned and guaranteed. 


\section{CONCLUSION}

In this study, there was a contradiction between the acceptance and the attitude of HPs to be questioned by the patient about $\mathrm{HH}$, reflecting their lack of knowledge of the $\mathrm{WHO}$ program and the need to implement educational practices in health. These results point to the need for a great investment in $\mathrm{HH}$ policies in Brazilian hospitals, institutions which have a scenario that is similar to the one found in the present study, which possibly can also extended to the reality of other developing countries. Actions aimed at training strategies that can clarify and strengthen HPs regarding indications, recommendations and situations/moments in which $\mathrm{HH}$ should be performed, as well as the choice of type of $\mathrm{HH}$ to be adopted and products to be used, should be prioritized and planned as permanent action in healthcare institutions.
The barriers to HPs knowledge, perceptions and attitudes express a distancing from national and international guidelines for $\mathrm{HH}$, reinforced in several other WHO-supported documents in campaigns proposed since the World Alliance for Patient Safety. Another point to highlight is the importance of disseminating knowledge about the five moments for $H H$, which should be a tireless aim of those responsible for training, qualifying and monitoring of the quality of care in institutions.

All of this may also explain the controversy, which consists of: on one hand, the professionals present a predominant feeling of discomfort before being questioned by the patient; on the other hand, their acceptance regarding the patient participation in incentivizing and reminding the HPs about $\mathrm{HH}$ is high, being, therefore, due to the obligation to implement strategies that stimulate this action.

\section{REFERENCES}

1. World Health Organization (WHO). WHO guidelines on hand hygiene in health care. First global patient safety challenge clean care is safer care. Geneva: WHO; 2009. 270p.

2. World Health Organization (WHO). A guide to the implementation of the WHO multimodal hand hygiene improvement strategy. Genebra: WHO; 2009. 48p.

3. Brasil. Agência Nacional de Vigilância Sanitária. Segurança do Paciente em Serviços de Saúde: Higienização das Mãos / Agência Nacional de Vigilância Sanitária. Brasília: Anvisa; 2009. 105p.

4. Allegranzi B, Gayet-Ageron A, Damani N, Bengaly L, McLaws ML, Moro ML, et al. Global implementation of WHO's multimodal strategy for improvement of hand hygiene: a quasi-experimental study. Lancet Infect Dis [Internet]. 2013 [cited 2017 Feb 23];13:843-51. Available from: http://dx.doi.org/10.1016/S1473-3099(13)70163-4

5. Tartari E, Pires D, Bellissimo-Rodrigues F, De Kraker M, Borzykowski TH, Allegranzi B, et al. The global hand-sanitizing relay: promoting hand hygiene through innovation. J Hosp Infect [Internet]. 2017 [cited 2017 Feb 23];95(2):189-93. Available from: http://www.journalofhospitalinfection.com/article/S0195-6701(16)30526-6/fulltext

6. Bathke J, Cunico PA, Maziero ECS, Cauduro FLF, Sarquis LMM, Cruz EDA. Infraestrutura e adesão à higienização das mãos: desafios à segurança do paciente. Rev Gaúcha Enferm [Internet]. 2013[cited 2017 Feb 23];34(2):78-85. Available from: http:// www.scielo.br/pdf/rgenf/v34n2/en_v34n2a10.pdf

7. Mertz D, Johnstone J, Krueger P, Brazil K, Walter SD, Loeb M. Adherence to hand hygiene and risk factors for poor adherence in 13 Ontario acute care hospitals. Am J Infect Control [Internet]. 2011 [cited 2017 Feb 23];39(8):693-6. Available from: http://www. ajicjournal.org/article/S0196-6553(11)00102-7/pdf

8. Primo MGB, Ribeiro LCM, Figueiredo LFS, Sirico SCA, Souza MA. Adesão à prática de higienização das mãos por profissionais de saúde de um Hospital Universitário. Rev Eletr Enf [Internet]. 2010 [cited 2017 Feb 23];12(2):266-71. Available from: http:// dx.doi.org/10.5216/10.5216/ree.v12i2.7656

9. Brasil, Assistência Segura: Uma Reflexão Teórica Aplicada a Prática. Brasília: ANVISA; 2013.172p.

10. Mcguckin M, Waterman R, Storr IJ, Bowler IC, Ashby M, Topley K, Porten L. Evaluation of a patient-empowering hand hygiene programme in the UK. J Hosp Infect [Internet]. 2014 [cited 2017 Feb 23];8(3):222-7. Available from: http://dx.doi.org/10.1053/ jhin.2001.0983

11. Kim MK, Nam EY, Na SH, Shin MJ, Lee HS, Kim NH, et al. Discrepancy in perceptions regarding patient participation in hand hygiene between patients and health care workers. Am J Infect Control [Internet]. 2015 [cited 2017 Feb 23];43(5):510-5. Available from: http://www.ajicjournal.org/article/S0196-6553(15)00036-X/pdf

12. Ciofi degli Atti ML, Tozzi AE, Ciliento G, Pomponi M, Rinaldi S, Raponi M. Healthcare workers' and parents' perceptions of measures for improving adherence to hand-hygiene. BMC Public Health [Internet]. 2011 [cited 2017 Feb 23]; 13(11):466. Available from: https://bmcpublichealth.biomedcentral.com/articles/10.1186/1471-2458-11-466

13. Prado MF, Hartmann TPS, Teixeira FLA. Acessibilidade da estrutura física hospitalar para a prática da higienização das mãos. Esc Anna Nery Rev Enferm [Internet]. 2013 [cited 2017 Feb 23];17(2):220-6. Available from: http://www.scielo.br/pdf/ean/v17n2/ v17n2a03.pdf

14. Mathur P. Hand hygiene: back to the basics of infection control. Indian J Med Res [Internet]. 2011 [cited 2016 Jun 30];134(5):611-20. 
Available from: https://www.ncbi.nlm.nih.gov/pmc/articles/PMC3249958/

15. Brasil. Resolução-RDC N.42, de 25 de outubro de 2010. Dispõe sobre a obrigatoriedade de disponibilização de preparação alcoólica para fricção antisséptica das mãos, pelos serviços de saúde do País, e dá outras providências. Brasília, 2010.

16. Damasceno QS, Iquiapaza R, Oliveira AC. Comparing resistant microorganisms isolated from patients and environment in an intensive care unit. Adv Infec Dis [Internet]. 2014 [cited 2017 Feb 23];4(1):30-5. Available from: https://www.scirp.org/journal/ PaperInformation.aspx?PaperID $=43408$

17. Souza LM, Ramos MF, Becker ESS, Meirelles LCS, Monteiro SAO. Adherence to the five moments for hand hygiene among intensive care professionals. Rev Gaúcha Enferm [Internet]. 2015 [cited 2017 Feb 23];36(4):21-28. Available from: http://www. scielo.br/pdf/rgenf/v36n4/1983-1447-rgenf-36-04-00021.pdf

18. Findik UY, Otkun MT, Erkan T, Sut N. Evaluation of handwashing behavior and analysis of hand flora of intensive care unit nurses. Asian Nurs Res [Internet]. 2011 [cited 2017 Feb 23];5(2):99-107. Available from: https://linkinghub.elsevier.com/retrieve/ pii/S1976-1317(11)60018-2

19. Pan SC, Tien KL, Hung IC, Lin YJ, Yang YL, Yang MC, et al. Patient empowerment in a hand hygiene program: differing points of view between patients/family members and health care workers in Asian culture. Am J Infect Control [Internet]. 2013 [cited 2016 Jun 30];41(11):979-83. Available from: https://www.ncbi.nlm.nih.gov/pubmed/23706832

20. Longtin Y, Farquet N, Gayet-Ageron A, Sax H, Pittet D. Caregivers' perceptions of patients as reminders to improve hand hygiene. Arch Intern Med [Internet]. 2012 [cited 2017 Feb 23];172(19):1516-7. Available from: http://jamanetwork.com/journals/ jamainternalmedicine/fullarticle/1356536

21. Pittet D, Panesar SS, Wilson K, Longtin Y, Morris T, Allan V, et al. Involving the patient to ask about hospital hand hygiene: a National Patient Safety Agency feasibility study. J Hosp Infect [Internet]. 2011 [cited 2017 Feb 23];77(4):299-303. Available from: http://www.journalofhospitalinfection.com/article/S0195-6701(10)00469-X/fulltext

22. Seale H, Travaglia J, Chughtai AA, Phillipson L, Novytska Y, Kaur R, et al. 'I don't want to cause any trouble': the attitudes of hospital patients towards patient empowerment strategies to reduce healthcare-acquired infections. J Infect Prevent [Internet]. 2015 [cited 2017 Feb 23];16:167-73. Available from: http://journals.sagepub.com/doi/abs/10.1177/1757177415588378 